\title{
A study on women's health information needs in menopausal age
}

\author{
Sadrieh Hajesmaeel-Gohari ${ }^{1}$, Elaheh Shafiei ${ }^{1 *} \mathbb{C}$, Fatemeh Ghasemi ${ }^{1}$ and Kambiz Bahaadinbeigy ${ }^{2}$
}

\begin{abstract}
Menopause is a natural event experienced by women in middle age. To help women manage this event, it is important to identify their health information needs. A study specific questionnaire was used to identify menopausal women's health information needs and the resources and challenges related to finding information about menopause. A total of 301 women aged 48-55 years completed the questionnaire. Data were analysed using negative binomial regression and chi-square tests. The most frequently sought information was that related to breast cancer ( $n=209,69.5 \%)$, hot flushes ( $n=200,66.5 \%)$, cervical cancer $(n=194,64.5 \%)$, non-hormonal therapies for menopausal symptoms $(n=192,64 \%)$, laboratory tests $(n=189,63 \%)$ and joint and muscle pain $(n=188,62.5 \%)$. The main sources of information were audiovisual media $(n=171,57 \%)$, obstetricians $(n=165,55 \%)$, friends $(n=157,52 \%)$, family $(n=157,52 \%)$ and the internet $(n=153,51 \%)$. The two main challenges were not knowing how to correctly access information $(n=115,38 \%)$ and not being aware of reliable sources of information $(n=108,36 \%)$. Therefore, it is essential for policymakers and decision-makers to provide reliable and accurate information to increase awareness and reduce anxiety of women experiencing menopause.
\end{abstract}

Keywords: Menopause, Health information needs, Information sources, Challenges

\section{Introduction}

Menopause results from a cease in ovarian follicular function and marks the end of menstruation. Clinically, menopause is diagnosed after 12 months of amenorrhea [1]. Menopause occurs either naturally or is surgically or medically induced. The number of middle-aged women is growing rapidly. In 1990, the number of women aged 50 years and over was estimated at 467 million globally, and this is expected to increase to about 1200 million by 2030 [2]. Most women experience menopause between the ages of 40 and 58 years [3]. The mean age of menopause is 51 years [3], and in Iran it is 48 years [4]. Given their increased life expectancy, women are currently spending around a third of their lives in postmenopause, potentially affecting their health and quality of life [5].

*Correspondence: e.shafiei.sh@gmail.com

${ }^{1}$ Medical Informatics Research Center, Institute for Futures Studies

in Health, Kerman University of Medical Sciences, Kerman, Iran

Full list of author information is available at the end of the article
The risk of non-communicable diseases such as cardiovascular disease, diabetes, chronic respiratory disease and cancer increases following menopause [6]. Studies show that non-communicable diseases affect more women than men [7] and are the main cause of death in women globally [8]. Improving women's knowledge by providing equitable and easy access to reliable information could help reduce the rate of non-communicable diseases and improve their health [9].

Most women experience some symptoms during menopause. Vasomotor symptoms such as night sweats and hot flushes are the only symptoms specifically linked to menopause [10, 11], affecting $60-80 \%$ of menopausal women [12]. The majority of women rate these symptoms as moderate to severe [13]. Factors that can affect the severity of these symptoms include sociodemographic characteristics, lifestyle factors, psychological status and being in a dyadic relationship [14]. The provision of effective and reliable educational materials can strongly

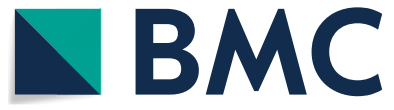

(c) The Author(s) 2021. Open Access This article is licensed under a Creative Commons Attribution 4.0 International License, which permits use, sharing, adaptation, distribution and reproduction in any medium or format, as long as you give appropriate credit to the original author(s) and the source, provide a link to the Creative Commons licence, and indicate if changes were made. The images or other third party material in this article are included in the article's Creative Commons licence, unless indicated otherwise in a credit line to the material. If material is not included in the article's Creative Commons licence and your intended use is not permitted by statutory regulation or exceeds the permitted use, you will need to obtain permission directly from the copyright holder. To view a copy of this licence, visit http://creativecommons.org/licenses/by/4.0/. The Creative Commons Public Domain Dedication waiver (http://creativeco mmons.org/publicdomain/zero/1.0/) applies to the data made available in this article, unless otherwise stated in a credit line to the data. 
encourage menopausal women to engage in self-care and personally manage or treat their symptoms [15], improving their health and quality of life [16]. Studies show that most women have a poor understanding of menopause $[17,18]$. According to a study in Iran, only about $1 \%$ of middle-aged women have satisfactory knowledge about menopause [19].

To inform women about menopause, it is first necessary to identify their information needs. Trudeau et al. [20] found that the most frequent information needs of postmenopausal women are related to menopausal symptoms, how to manage them and alternative therapies. Women seek information about managing the effects of menopause from a variety of sources, including friends, family, healthcare providers, television, radio, books, pamphlets, videos and the internet [20-22].

Studies on the information needs of menopausal women are limited, and none have previously been conducted in Iran. The purpose of this study is to investigate the information needs of menopausal women in Iran, their knowledge about menopause and interest in learning more, the sources they typically use and the challenges they face in finding information.

\section{Methods \\ Participants}

This cross-sectional study was conducted in Iran from September 2020 to March 2021. The initial sample included 258 women aged 48-55 years; however, to reduce sampling error, the sample size was increased to 301 women. Cochran's formula $(z=1.96, p=0.41$, $q=0.59, d=0.06)$ was used to calculate sample size. The $p$ value was obtained from a previous study [20].

\section{Questionnaire design}

Data were collected using a study specific questionnaire, the design of which was based on those used in similar studies [20, 22-24] and the expert opinions of two obstetricians. The questionnaire was evaluated and approved by two health informatics specialists with a background in general medicine, two health information management specialists and two obstetricians. Questionnaire reliability and internal consistency was confirmed (Cronbach's alpha $=0.93$ ). Fifteen participants were selected and asked to test the questionnaire. Based on the results of the pilot test, there was no need to change the content of the questionnaire.

The questionnaire included the following five sections:

- Section 1: Demographic information: age, marital status and education.

- Section 2: Three questions related to level of knowledge, level of interest in information and the fre- quency of searching for information about menopause, respectively. The first two questions were based on a 5-point scale ranging from very little to very much. The third question was based on a 5-point scale comprising daily, weekly, monthly, rarely and never.

- Section 3: Information sought by menopausal women, comprising 42 items across six categories: cancers (three items), other diseases (three items), menopausal symptoms (20 items), health care consultations (four items), diagnostic methods (four items) and treatments (eight items).

- Section 4: Sources used to acquire information about menopause (15 items).

- Section 5: Challenges in searching for information about menopause (seven items).

Sections 3-5 presented yes or no options. An open question at the end of the questionnaire invited participants to provide any additional information.

\section{Data collection}

The questionnaire was distributed to participants either on paper or electronically. Most questionnaires were distributed to women 48-55 years of age attending the Arad Medical Centre (either as a patient or as an accompanying person). The centre offers a range of medical specialties, including gynaecology, in the city of Kerman. After explaining the purpose of the study and assuring potential participants' of data confidentiality, informed consent was obtained. Further, because of the COVID-19 pandemic and the need for social distancing, a link to an online questionnaire was distributed via WhatsApp and Telegram. Data collection continued until the estimated sample size $(N=301)$ was met.

\section{Data analysis}

Data were analysed by means of descriptive and analytic statistics. The Negative binomial regression model was used to compare the differences between the mean number of information items that women may need to know during menopause in every six groups and different groups of age, marital status, and educational status. Married women aged 48-51 years and without a high school diploma comprised the reference group. A chi-square test was used to examine the association between age, marital status and education and the level of knowledge, the level of interest in obtaining information, the level of need for information about menopause, the sources used to acquire information and challenges in searching for information. Data were analysed using SPSS version 22.0. 


\section{Results}

\section{Demographic characteristics}

A total of 301 women aged 48-55 years completed the questionnaire. The mean age of participants was $51.5 \pm 2.53$ years. Just over half of the women were aged $48-51$ years $(n=152,50.5 \%)$. Most participants were married $(n=226,75 \%)$ and had no academic degree $(n=176,58.5 \%)$. Table 1 shows the demographic characteristics of participants.

\section{Knowledge, interest and need levels}

More than half of the participants rated their level of knowledge about menopause as 'somewhat' ( $n=155$, $51.5 \%)$. More than one-third of participants were 'somewhat' interested in obtaining information $(n=123,41 \%)$. Less than half of the respondents indicated that they 'rarely' needed to search for information about menopause $(n=136,45 \%)$ (see Table 2$)$. The results of the chi-square test show statistically significant relationships between age group and knowledge level and between educational status and both knowledge and interest levels $(p<0.05)$ (see Table 2).

\section{Information needs}

Table 3 shows 42 information items that women may need to know about menopause. The information most frequently needed was that related to breast cancer $(n=209,69.5 \%)$, hot flushes $(n=200,66.5 \%)$, cervical cancer $(n=194,64.5 \%)$, non-hormonal therapies for menopausal symptoms $(n=192,64 \%)$, laboratory tests $(n=189,63 \%)$ and joint and muscle pain $(n=188,62.5 \%)$. The information least frequently needed was related to consultations to reduce or quit smoking $(n=76,25 \%)$, infertility $(n=84,28 \%)$, men's sexual problems $(n=89$, $29.5 \%)$, women's sexual problems $(n=115,38 \%)$, hair

Table 1 Demographic characteristics of studied women

\begin{tabular}{lc}
\hline Characteristics & Number (\%) \\
\hline Age group & $152(50.5)$ \\
$48-51$ years & $149(49.5)$ \\
$52-55$ years & \\
Marital status & $13(4.5)$ \\
Single & $226(75)$ \\
Married & $28(9.5)$ \\
Divorced & $34(11)$ \\
Widow & \\
Educational status & $84(28)$ \\
Without a highschool diploma & $92(30.5)$ \\
Diploma & $125(41.5)$ \\
Academic &
\end{tabular}

Table 2 The frequency of responses about the knowledge level, interest in obtaining, and need in searching information about menopause

\begin{tabular}{|c|c|c|c|c|}
\hline \multirow[t]{2}{*}{ Question } & \multirow[t]{2}{*}{ Number (\%) } & \multicolumn{3}{|l|}{$P$-value } \\
\hline & & Age group & $\begin{array}{l}\text { Marital } \\
\text { status }\end{array}$ & $\begin{array}{l}\text { Educational } \\
\text { status }\end{array}$ \\
\hline $\begin{array}{l}\text { Knowledge } \\
\text { level }\end{array}$ & & 0.014 & 0.063 & 0.000 \\
\hline Very little & $48(16)$ & & & \\
\hline little & $53(17.5)$ & & & \\
\hline Somewhat & $155(51.5)$ & & & \\
\hline Much & $39(13)$ & & & \\
\hline Very much & $6(2)$ & & & \\
\hline $\begin{array}{l}\text { Interest in } \\
\text { obtaining } \\
\text { information }\end{array}$ & & 0.639 & 0.346 & 0.001 \\
\hline Very little & $14(4.5)$ & & & \\
\hline little & $33(11)$ & & & \\
\hline Somewhat & $123(41)$ & & & \\
\hline Much & $100(33)$ & & & \\
\hline Very much & $31(10.5)$ & & & \\
\hline $\begin{array}{l}\text { Frequency } \\
\text { of needs in } \\
\text { searching } \\
\text { information }\end{array}$ & & 0.208 & 0.698 & 0.548 \\
\hline Daily & $10(3.5)$ & & & \\
\hline Weekly & $32(10.5)$ & & & \\
\hline Monthly & $94(31.5)$ & & & \\
\hline Rarely & $136(45)$ & & & \\
\hline Never & $29(9.5)$ & & & \\
\hline
\end{tabular}

and nail problems $(n=130,43 \%)$ and consultations about exercise $(n=130,43 \%)$.

The mean number of selected information items in all categories (except consultations) was higher in the $52-55$-year age group than in the 48-51-year age group $(p<0.05)$. The mean number of selected information items in all categories (except consultations) was significantly higher for widowed women than for married women. Moreover, compared with married women, divorced women sought more information on diseases, menopausal symptoms and treatments $(p<0.05)$. Single women required more information about treatments. Women with academic degrees required more information about all categories compared with those without (see Table 4).

\section{Information sources}

Table 5 shows that 15 sources were used to obtain information. The most frequently used sources were audiovisual media $(n=171,57 \%)$, obstetricians $(n=165,55 \%)$, friends $(n=157,52 \%)$, family $(n=157,52 \%)$ and the internet $(n=153,51 \%)$. The least frequently used sources 
Table 3 The frequency of "yes" responses to information items that women may need to know about menopause

\begin{tabular}{|c|c|}
\hline Information items & Number (\%) \\
\hline \multicolumn{2}{|l|}{ Women's cancers } \\
\hline Breast cancer & $209(69.5)$ \\
\hline Cervical cancer & $194(64.5)$ \\
\hline Ovarian cancer & $173(57.5)$ \\
\hline \multicolumn{2}{|l|}{ Diseases } \\
\hline Colon cancer & $163(54)$ \\
\hline Uterine fibroid & $178(59)$ \\
\hline Uterine prolapse & $179(59.5)$ \\
\hline \multicolumn{2}{|l|}{ Menopause symptoms } \\
\hline Hot flashes & $200(66.5)$ \\
\hline Night sweats & $147(49)$ \\
\hline Menstrual changes & $168(56)$ \\
\hline Sleep pattern changes & $160(53)$ \\
\hline Depression & $173(57.5)$ \\
\hline Anxiety & $151(50)$ \\
\hline Alzheimer & $145(48)$ \\
\hline Decreased concentration & $153(51)$ \\
\hline Urinary problems & $136(45)$ \\
\hline Skin problems & $134(44.5)$ \\
\hline Hair and nail problems & $130(43)$ \\
\hline Sexual problems for women & $115(38)$ \\
\hline Sexual problems for men & $89(29.5)$ \\
\hline Infertility & $84(28)$ \\
\hline Blood pressure & $170(56.5)$ \\
\hline Diabetes & $141(47)$ \\
\hline Obesity & $165(55)$ \\
\hline Cardiovascular problems & $151(50)$ \\
\hline Bone problems & $164(54.5)$ \\
\hline Joint and muscle ache & $188(62.5)$ \\
\hline \multicolumn{2}{|l|}{ Consultations } \\
\hline Consultation about exercise & $130(43)$ \\
\hline Consultation about dietary & $171(57)$ \\
\hline Consultation about reducing or quitting smoking & $76(25)$ \\
\hline Consultation about maintaining a healthy weight & $173(57.5)$ \\
\hline \multicolumn{2}{|l|}{ Diagnosis methods } \\
\hline Sonography & $160(53)$ \\
\hline Mammography & $172(57)$ \\
\hline Bone Mineral Densitometry & $187(62)$ \\
\hline Laboratory tests & $189(63)$ \\
\hline \multicolumn{2}{|l|}{ Treatments } \\
\hline A variety of treatments to reduce menopausal symptoms & $187(62)$ \\
\hline $\begin{array}{l}\text { Non-hormonal therapies to reduce menopausal symp- } \\
\text { toms }\end{array}$ & $192(64)$ \\
\hline $\begin{array}{l}\text { Hormonal therapies to reduce the symptoms of meno- } \\
\text { pause }\end{array}$ & $138(46)$ \\
\hline $\begin{array}{l}\text { Complementary therapies (traditional medicine, acupunc- } \\
\text { ture) }\end{array}$ & $173(57.5)$ \\
\hline Medicinal supplements (calcium tablets, ...) & $184(61)$ \\
\hline Side effects of treatments & $142(47)$ \\
\hline
\end{tabular}

Table 3 (continued)

\begin{tabular}{ll}
\hline Information items & Number (\%) \\
\hline Cost of treatment & $128(42.5)$ \\
Duration of treatment & $129(43)$ \\
\hline
\end{tabular}

were religious groups $(n=22,7.5 \%)$, workshops $(n=28$, $9 \%)$, pharmacists $(n=29,9.5 \%)$, nurses $(n=49,16.5 \%)$ and educational videos $(n=60,20 \%)$.

There were statistically significant relationships between age group and the use of written sources, audiovisual media, telephone consultations, family, friends, obstetricians, midwives, pharmacists, nurses and traditional medicine specialists or herbalists $(p<0.05)$. Significant relationships were also found between marital status and seeking information from audiovisual media, the internet and family members and between educational status and seeking information from written sources, audiovisual media, educational videos, the internet and groups $(p<0.05)$.

\section{Challenges in finding information}

Table 6 shows seven challenges women face when searching for information about menopause. The most frequent challenges faced by participants were not knowing how to correctly access information $(n=115,38 \%)$ and not being aware of reliable sources of information $(n=108$, $36 \%)$. The least frequent challenges were menopausal symptoms $(n=67,22.5 \%)$ and limited access to information $(n=82,27 \%)$.

A statistically significant relationship was found between age group and the following two challenges: contradictions between different sources and limited access to information $(p<0.05)$. Significant relationships were also found between marital status and being aware of sources of information and between educational status and not finding enough information and limited access to information $(p<0.05)$.

\section{Discussion}

This study was conducted to identify the health information needs of menopausal women as well as the sources used to seek information and the challenges faced while searching for information.

Most participants sought information about breast cancer, hot flushes, cervical cancer, non-hormonal therapies, laboratory tests and joint and muscle pain. This finding is similar to that of a study conducted on midlife women in Singapore [23], which showed that gynaecological cancers, joint and muscle pain, bone health and breast cancer testing were the most commonly selected 
Table 4 The Negative binominal regression model to compare the differences between the mean numbers of information needed items

\begin{tabular}{|c|c|c|c|}
\hline & Mean \pm S.D & $\begin{array}{l}\text { Regression coefficient* }(95 \% \text { confidence } \\
\text { interval) }\end{array}$ & $P$-value \\
\hline \multicolumn{4}{|l|}{ Women's cancers } \\
\hline \multicolumn{4}{|l|}{ Age group } \\
\hline $48-51$ & $2.27 \pm 1.63$ & Reference & Reference \\
\hline $52-55$ & $1.85 \pm 1.61$ & $1.23(1.06,1.41)$ & 0.004 \\
\hline \multicolumn{4}{|l|}{ Marital status } \\
\hline Married & $1.77 \pm 1.20$ & Reference & Reference \\
\hline Single & $2.17 \pm 1.08$ & $1.22(0.93,1.62)$ & 0.147 \\
\hline Divorced & $2.04 \pm 1.25$ & $1.15(0.91,1.46)$ & 0.226 \\
\hline Widow & $2.25 \pm 1.35$ & $1.27(1.01,1.60)$ & 0.039 \\
\hline \multicolumn{4}{|l|}{ Educational status } \\
\hline Without a highschool diploma & $1.80 \pm 1.50$ & Reference & Reference \\
\hline Diploma & $2.03 \pm 1.61$ & $1.12(0.91,1.39)$ & 0.262 \\
\hline Academic & $2.35 \pm 1.53$ & $1.30(1.07,1.59)$ & 0.009 \\
\hline \multicolumn{4}{|l|}{ Diseases } \\
\hline \multicolumn{4}{|l|}{ Age group } \\
\hline $48-51$ & $1.75 \pm 1.49$ & Reference & Reference \\
\hline $52-55$ & $2.02 \pm 1.51$ & $1.51(0.99,1.33)$ & 0.058 \\
\hline \multicolumn{4}{|l|}{ Marital status } \\
\hline Married & $1.57 \pm 1.12$ & Reference & Reference \\
\hline Single & $1.70 \pm 1.04$ & $1.08(0.77,1.51)$ & 0.650 \\
\hline Divorced & $2.28 \pm 0.77$ & $1.45(1.25,1.69)$ & 0.000 \\
\hline Widow & $2.06 \pm 1.30$ & $1.31(1.03,1.67)$ & 0.024 \\
\hline \multicolumn{4}{|l|}{ Educational status } \\
\hline Without a highschool diploma & $1.72 \pm 1.36$ & Reference & Reference \\
\hline Diploma & $1.84 \pm 1.44$ & $1.07(0.87,1.31)$ & 0.514 \\
\hline Academic & $2.10 \pm 1.53$ & $1.22(0.99,1.49)$ & 0.052 \\
\hline \multicolumn{4}{|l|}{ Menopause symptoms } \\
\hline \multicolumn{4}{|l|}{ Age group } \\
\hline $48-51$ & $9.43 \pm 8.75$ & Reference & Reference \\
\hline $52-55$ & $11.96 \pm 9.39$ & $1.26(1.09,1.47)$ & 0.002 \\
\hline \multicolumn{4}{|l|}{ Marital status } \\
\hline Married & $8.76 \pm 6.31$ & Reference & Reference \\
\hline Single & $9.13 \pm 6.22$ & $1.04(0.71,1.52)$ & 0.831 \\
\hline Divorced & $12.50 \pm 5.76$ & $1.42(1.17,1.72)$ & 0.000 \\
\hline Widow & $12.74 \pm 7.28$ & $1.45(1.17,1.80)$ & 0.001 \\
\hline \multicolumn{4}{|l|}{ Educational status } \\
\hline Without a highschool diploma & $10.24 \pm 7.78$ & Reference & Reference \\
\hline Diploma & $9.52 \pm 8.43$ & $0.93(0.75,1.14)$ & 0.486 \\
\hline Academic & $12.31 \pm 9.50$ & $1.20(0.99,1.45)$ & 0.057 \\
\hline \multicolumn{4}{|l|}{ Consultations } \\
\hline \multicolumn{4}{|l|}{ Age group } \\
\hline $48-51$ & $1.77 \pm 1.80$ & Reference & Reference \\
\hline $52-5$ & $1.98 \pm 1.86$ & $1.11(0.93,1.32)$ & 0.218 \\
\hline \multicolumn{4}{|l|}{ Marital status } \\
\hline Married & $1.64 \pm 1.32$ & Reference & Reference \\
\hline Single & $1.69 \pm 0.91$ & $1.03(0.76,1.39)$ & 0.849 \\
\hline Divorced & $2.08 \pm 1.56$ & $1.27(0.95,1.69)$ & 0.101 \\
\hline Widow & $2.14 \pm 1.88$ & $1.30(0.94,1.80)$ & 0.103 \\
\hline
\end{tabular}


Table 4 (continued)

\begin{tabular}{|c|c|c|c|}
\hline & Mean \pm S.D & $\begin{array}{l}\text { Regression coefficient* ( } 95 \% \text { confidence } \\
\text { interval) }\end{array}$ & $P$-value \\
\hline \multicolumn{4}{|l|}{ Education } \\
\hline Without a highschool diploma & $1.58 \pm 1.56$ & Reference & Reference \\
\hline Diploma & $1.69 \pm 1.66$ & $1.06(0.82,1.38)$ & 0.618 \\
\hline Academic & $2.45 \pm 1.99$ & $1.55(1.23,1.94)$ & 0.000 \\
\hline \multicolumn{4}{|l|}{ Diagnosis methods } \\
\hline \multicolumn{4}{|l|}{ Age group } \\
\hline $48-51$ & $2.15 \pm 1.92$ & Reference & Reference \\
\hline $52-55$ & $2.79 \pm 2.12$ & $1.29(1.11,1.49)$ & 0.001 \\
\hline \multicolumn{4}{|l|}{ Marital status } \\
\hline Married & $2.12 \pm 1.44$ & Reference & Reference \\
\hline Single & $2.29 \pm 1.36$ & $1.08(0.77,1.50)$ & 0.646 \\
\hline Divorced & $2.78 \pm 1.30$ & $1.31(1.08,1.58)$ & 0.004 \\
\hline Widow & $2.67 \pm 1.60$ & $1.26(1.01,1.57)$ & 0.036 \\
\hline \multicolumn{4}{|l|}{ Education } \\
\hline Without a highschool diploma & $2.31 \pm 1.70$ & Reference & Reference \\
\hline Diploma & $2.06 \pm 1.84$ & $0.89(0.72,1.09)$ & 0.278 \\
\hline Academic & $3.10 \pm 2.00$ & $1.34(1.14,1.57)$ & 0.000 \\
\hline \multicolumn{4}{|l|}{ Treatments } \\
\hline \multicolumn{4}{|l|}{ Age group } \\
\hline $48-51$ & $4.32 \pm 3.79$ & Reference & Reference \\
\hline $52-55$ & $5.28 \pm 3.87$ & $1.22(1.03,1.44)$ & 0.016 \\
\hline \multicolumn{4}{|l|}{ Marital status } \\
\hline Married & $3.75 \pm 2.88$ & Reference & Reference \\
\hline Single & $5.15 \pm 2.31$ & $1.37(1.06,1.78)$ & 0.016 \\
\hline Divorced & $5.24 \pm 2.85$ & $1.40(1.12,1.74)$ & 0.003 \\
\hline Widow & $5.15 \pm 3.39$ & $1.37(1.07,1.76)$ & 0.011 \\
\hline \multicolumn{4}{|l|}{ Education } \\
\hline Without a highschool diploma & $4.41 \pm 3.62$ & Reference & Reference \\
\hline Diploma & $4.38 \pm 3.44$ & $0.99(0.79,1.24)$ & 0.958 \\
\hline Academic & $5.65 \pm 4.22$ & $1.28(1.04,1.57)$ & 0.019 \\
\hline
\end{tabular}

*Exponentiation of the B coefficient (EXP (B))

topics. Breast cancer is the most common cancer in women worldwide, including in Iran. Hormonal replacement therapy following menopause is a risk factor for breast cancer [25]. While hormonal therapies are effective in the treatment of menopausal vasomotor symptoms, many women prefer non-hormonal treatments because of the side effects of hormonal therapies and their limited use in some cancers [26]. This indicates the importance of providing information about breast cancer and non-hormonal menopausal treatments.

Cervical cancer was another issue considered by participants in this study. In Iran, cervical cancer mainly occurs in postmenopausal women aged $55-65$ years. The incidence of cervical cancer in Iran is 2.5 per 100,000 women, the average mortality rate is 1.04 per 100,000 , and the mortality-to-incidence ratio is $42 \%$ [27]. These statistics and the findings of the present study reveal the importance of providing sufficient information about cervical cancer and its risk factors to reduce its prevalence.

Participants also frequently sought information about hot flushes and joint and muscle pain, two of the most common symptoms experienced by menopausal Iranian women [28, 29], which provides a possible explanation for our results.

Information about treatments to reduce or quit smoking, infertility and men and women's sexual problems was sought less frequently. The prevalence of smoking in Iran is moderate compared with other Asian countries-only $3 \%$ of Iranian women smoke cigarettes [30], which may explain why few women search for information about reducing or quitting smoking. Seeking information about sexual issues may be less common because of the shame or taboo associated with these issues in the Iranian sociocultural context. Shame is frequently a barrier to seeking 
Table 5 The frequency of sources used to acquire information about menopause

\begin{tabular}{|c|c|c|c|c|}
\hline \multirow[t]{2}{*}{ Source } & \multirow[t]{2}{*}{ Number (\%) } & \multicolumn{3}{|l|}{$p$-value } \\
\hline & & Age group & Marital status & $\begin{array}{l}\text { Educational } \\
\text { status }\end{array}$ \\
\hline $\begin{array}{l}\text { Written sources (books, brochures, magazines, newspa- } \\
\text { pers, articles) }\end{array}$ & $119(39.5)$ & 0.056 & 0.593 & 0.000 \\
\hline Audio-visual media (TV, radio) & $171(57)$ & 0.000 & 0.025 & 0.040 \\
\hline Educational videos & $60(20)$ & 0.069 & 0.365 & 0.045 \\
\hline Telephone consultation & $52(17.5)$ & 0.005 & 0.516 & 0.067 \\
\hline Internet (websites and social networks) & $153(51)$ & 0.602 & 0.044 & 0.000 \\
\hline Family & $157(52)$ & 0.001 & 0.050 & 0.434 \\
\hline Friends & $157(52)$ & 0.056 & 0.108 & 0.643 \\
\hline Obstetricians & $165(55)$ & 0.031 & 0.432 & 0.114 \\
\hline General Practitioners & $78(26)$ & 0.248 & 0.756 & 0.209 \\
\hline Midwives & $79(26.5)$ & 0.001 & 0.449 & 0.342 \\
\hline Pharmacists & $29(9.5)$ & 0.027 & 0.399 & 0.155 \\
\hline Nurses & $49(16.5)$ & 0.016 & 0.454 & 0.143 \\
\hline Specialists in traditional medicine or herbalists & $102(34)$ & 0.002 & 0.365 & 0.908 \\
\hline Workshops & $28(9)$ & 0.100 & 0.633 & 0.206 \\
\hline Religious groups & $22(7.5)$ & 0.168 & 0.097 & 0.356 \\
\hline
\end{tabular}

Table 6 The frequency of challenges in searching information about menopause

\begin{tabular}{|c|c|c|c|c|}
\hline \multirow[t]{2}{*}{ Challenge } & \multirow[t]{2}{*}{ Number (\%) } & \multicolumn{3}{|l|}{$P$-value } \\
\hline & & Age group & Marital status & $\begin{array}{l}\text { Educational } \\
\text { status }\end{array}$ \\
\hline Information from different sources is contradictory & $106(35)$ & 0.040 & 0.114 & 0.329 \\
\hline I do not have enough time to search information & $106(35)$ & 0.187 & 0.788 & 0.916 \\
\hline I do not find enough information & $103(34)$ & 0.806 & 0.124 & 0.040 \\
\hline I do not know the sources of information & $108(36)$ & 0.897 & 0.028 & 0.131 \\
\hline I do not know how to access information correctly & $115(38)$ & 0.466 & 0.481 & 0.359 \\
\hline I have limited access to information (library, internet, etc.) & $82(27)$ & 0.055 & 0.077 & 0.022 \\
\hline $\begin{array}{l}\text { Menopausal symptoms prevent the search for information } \\
\text { (Decreased memory or concentration, lack of energy, mood } \\
\text { swings, etc.) }\end{array}$ & $67(22.5)$ & 0.548 & 0.909 & 0.858 \\
\hline
\end{tabular}

health information for women [31]. However, sexual problems increase with age, a decrease in oestrogen levels and menopause and can affect life satisfaction [32, 33].

The most frequently used information sources were audiovisual media, obstetricians, friends, family and the internet. In contrast, a study conducted on middle-aged Brazilian women found that the most frequently used sources of information were friends, family, physicians and audiovisual media, while the least frequently used source was the internet [21]. However, this difference is most likely related to the data being gathered in 2012 and 2013, meaning that public access to the internet was limited. Moreover, there were few discussions about menopause in the Brazilian media, which was used much less as a source compared with friends, family and physicians [21].

The most frequent challenges in finding information were related to not knowing how to access information and not being aware of reliable sources of information. This shows the need for healthcare providers to educate women about menopause. Educational programs could increase women's knowledge about this critical topic $[17,20]$. A previous study on women's information needs about complementary and alternative treatments for menopause symptoms showed contrasting results [24]. In this study, the greatest challenges were information gaps, contradictory information and limited time to search for information. These differences may be 
related to the fact that the study investigated challenges in searching for information about a particular treatment for menopausal symptoms, while our study investigated challenges in searching for information about all aspects of menopause.

More than half of the participants in our study rated their level of knowledge about menopause as 'somewhat'. This result is consistent with a previous study that found that most women had moderate knowledge about menopause [19]. We also found that women with academic degrees had more knowledge and interest in obtaining information about menopause. A study on Jordanian women's knowledge about menopause showed the same result [34]. It is likely that women with an academic degree have more knowledge and interest in finding information about menopause because they are more capable of searching for reliable information.

To the best of our knowledge, this is the first study on the information needs of menopausal women in Iran. However, it has some limitations. Because of the COVID19 pandemic, participation in the questionnaire was less than expected, meaning that we had to create an online version. This may have influenced the findings, especially the finding related to the internet as one of the most frequently used information sources.

\section{Conclusion}

Menopause is a natural stage in the life of middle-aged women and can have a significant impact on quality of life. Identifying the information needs of menopausal women can help in the design of practical training programs, raise levels of awareness and improve quality of life. The findings of this study show that women require various types of information, particularly information about cancers, the clinical signs of menopause and non-hormonal therapies for menopausal symptoms. Therefore, it is important that health policymakers and decision-makers provide reliable and accurate information about these aspects to improve women's understanding of menopause and help ensure peace of mind.

\section{Acknowledgements \\ We thank Dr Yunes Jahani for collaborating in data analysis and interpre- tation. We also thank Fatemeh Sarpourian for helping us complete the questionnaires.}

\section{Authors' contributions}

S. Hajesmaeel-Gohari, K. Bahaadinbeigy and F. Ghasemi contributed to the concept and design of the study. S. Hajesmaeel-Gohari and E. Shafiei contributed to the acquisition and interpretation of data and drafting the article. All authors read and approved the final version of the article.

\section{Funding}

This study was funded by Kerman University of Medical Sciences (research ID 99000305).

\section{Availability of data and materials}

The datasets used and/or analysed during the current study available from the corresponding author on reasonable request.

\section{Declarations}

Ethical approval and consent to participate

This study was approved by the Kerman University of Medical Sciences Ethics Committee (Approval Code R.KMU.REC.1399.362). All methods were performed in accordance with the relevant guidelines and regulations. The written informed consent was obtained from all subjects.

\section{Consent for publication}

Not applicable.

\section{Competing interests}

The authors declare no competing interests.

\section{Author details}

${ }^{1}$ Medical Informatics Research Center, Institute for Futures Studies in Health, Kerman University of Medical Sciences, Kerman, Iran. ${ }^{2}$ Gastroenterology and Hepatology Research Center, Institute of Basic and Clinical Physiology Sciences, Kerman University of Medical Sciences, Kerman, Iran.

Received: 19 June 2021 Accepted: 22 December 2021

Published online: 28 December 2021

\section{References}

1. Greendale GA, Lee NP, Arriola ER. The menopause. Lancet (London, England). 1999;353(9152):571-80.

2. Research on the menopause in the 1990s, https://apps.who.int/iris/ bitstream/handle/10665/41841/WHO_TRS_866.pdf?sequence=1\&isAll owed =y

3. Menopause 101: A primer for the perimenopausal https://www.menop ause.org/for-women/menopauseflashes/menopause-symptoms-andtreatments/menopause-101-a-primer-for-the-perimenopausal

4. Saei Ghare Naz M, Sayehmiri F, Kiani F, Ozgoli G: A Systematic Review and Meta-analysis on the Average Age of Menopause among Iranian Women J Evid Based Care 2019, 8(4):26-34.

5. El Khoudary SR, Greendale G, Crawford SL, Avis NE, Brooks MM, Thurston RC, Karvonen-Gutierrez C, Waetjen LE, Matthews K. The menopause transition and women's health at midlife: a progress report from the Study of Women's Health Across the Nation (SWAN). Menopause (New York, NY). 2019;26(10):1213-27.

6. He L, Tang X, Hu YH: Relationship of menopause with cardiovascular disease and related metabolic disorders. Beijing da xue xue bao Yi xue ban $=$ Journal of Peking University Health sciences 2016, 48(3):448-453.

7. Global status report on noncommunicable diseases $2014 \mathrm{https}: / / \mathrm{apps}$. who.int/iris/handle/10665/148114

8. The top 10 causes of death https://www.who.int/news-room/fact-sheets/ detail/the-top-10-causes-of-death

9. Noncommunicable diseases: a priority for women's health and development https://www.who.int/pmnch/topics/maternal/2011_women_ncd_ report.pdf.pdf

10. Santoro N, Roeca C, Peters BA, Neal-Perry G. The menopause transition: signs, symptoms, and management options. J Clin Endocrinol Metab. 2021;106(1):1-15.

11. Weidner K, Croy I, Siepmann T, Brähler E, Beutel M, Bittner A. Menopausal syndrome limited to hot flushes and sweating a representative survey study. J Psychosom Obstet Gynaecol. 2017;38(3):170-9.

12. Thurston RC, Joffe H. Vasomotor symptoms and menopause: findings from the Study of Women's Health across the Nation. Obstet Gynecol Clin North Am. 2011;38(3):489-501.

13. Freeman EW, Sammel MD, Sanders RJ. Risk of long-term hot flashes after natural menopause: evidence from the Penn Ovarian Aging Study cohort. Menopause (New York, NY). 2014;21(9):924-32. 
14. Lee M-S, Kim J-H, Park MS, Yang J, Ko Y-H, Ko S-D, Joe S-H. Factors influencing the severity of menopause symptoms in Korean post-menopausal women. J Korean Med Sci. 2010;25(5):758-65.

15. Du H-S, Ma J-J, Li M. High-quality Health Information Provision for Stroke Patients. Chin Med J (Engl). 2016;129(17):2115-22.

16. Forouhari S, Khajehei M, Moattari M, Mohit M, Rad MS, Ghaem H. The effect of education and awareness on the quality-of-life in postmenopausal women. Indian J Community Med. 2010;35(1):109-14.

17. Gebretatyos H, Ghirmai L, Amanuel S, Gebreyohannes G, Tsighe Z, Tesfamariam EH. Effect of health education on knowledge and attitude of menopause among middle-age teachers. BMC Womens Health. 2020;20(1):232.

18. Smail L, Jassim GA, Sharaf KI. Emirati Women's knowledge about the menopause and menopausal hormone therapy. Int J Environ Res Public Health. 2020;17(13):4875.

19. Taherpour M, Sefidi F, Afsharinia S, Hamissi JH. Menopause knowledge and attitude among Iranian women. J Med Life 2015, 8(Spec Iss 2):72-76.

20. Trudeau KJ, Ainscough JL, Trant M, Starker J, Cousineau TM. Identifying the educational needs of menopausal women: a feasibility study. Womens Health Issues. 2011;21(2):145-52.

21. de Arruda Amaral ICG, Baccaro LF, Lui-Filho JF, Osis MJD, Pedro AO, CostaPaiva L. Opinions and main sources of information about menopause among middle-aged Brazilian women. Menopause (New York, NY). 2019;26(10):1154-9.

22. Domm JA, Parker EE, Reed GW, German DC, Eisenberg E. Factors affecting access to menopause information. Menopause (New York, NY). 2000;7(1):62-7.

23. Wong JU, Thu WPP, Lim CW, Wang YL, Yong EL, Logan SJS: Health information needs of 1000 midlife Singaporean women. Climacteric: J Int Menopause Soc 2020, 23(5):511-8.

24. Armitage GD, Suter E, Verhoef MJ, Bockmuehl C, Bobey M. Women's needs for CAM information to manage menopausal symptoms. Climacteric: J Int Menopause Soc. 2007;10(3):215-24.

25. Farhood B, Geraily G, Alizadeh A. Incidence and mortality of various cancers in iran and compare to other countries: a review article. Iran J Public Health. 2018;47(3):309-16.

26. Woyka J. Consensus statement for non-hormonal-based treatments for menopausal symptoms. Post Repro Health. 2017;23(2):71-5.

27. Khorasanizadeh F, Hassanloo J, Khaksar N, Taheri SM, Marzaban M, Rashidi BH, Sari AA, Zendehdel K. Epidemiology of cervical cancer and human papilloma virus infection among Iranian women: analyses of national data and systematic review of the literature. Gynecologic Oncol. 2013;128(2):277-81.

28. Masjoudi M, Amjadi MA, Leyli EKN. Severity and frequency of menopausal symptoms in middle aged women, Rasht, Iran. J Clin Diagn Res 2017, 11(8):OC17-21.

29. Delavar MA, Hajiahmadi M. Factors affecting the age in normal menopause and frequency of menopausal symptoms in Northern Iran. Iran Red Crescent Med J. 2011;13(3):192-8.

30. Mohammadian M, Sarrafzadegan N, Roohafza HR, Sadeghi M, Hasanzadeh A, Rejali MJWCRJ: A comparative study on the prevalence and related factors of cigarette smoking in Iran and other Asian countries: Results of Isfahan Cohort Study (ICS). 2018, 5(4).

31. Nikbakht Nasrabadi A, Sabzevari S, Negahban Bonabi T. Iranian Women's experiences of health information seeking barriers: a qualitative study in Kerman. Iran Red Crescent Med J. 2015;17(2):e25156-e25156.

32. Dąbrowska-Galas M, Dąbrowska J, Michalski B. Sexual dysfunction in menopausal women. Sexual Medicine. 2019;7(4):472-9.

33. Mostafa T, Mostafa RM, Hassan MM, Nasrallah YS, Salman WS, Taymour MJHA: Female sexual dysfunction among menopausal women. 2015, 5(2):23-27.

34. Alshogran OY, Mahmoud FM, Alkhatatbeh MJ: Knowledge and awareness toward menopause and hormone therapy among premenopausal women in Jordan. Climacteric: J Int Menopause Soc. 2021, 24(2):171-8.

\section{Publisher's Note}

Springer Nature remains neutral with regard to jurisdictional claims in published maps and institutional affiliations.

Ready to submit your research? Choose BMC and benefit from:

- fast, convenient online submission

- thorough peer review by experienced researchers in your field

- rapid publication on acceptance

- support for research data, including large and complex data types

- gold Open Access which fosters wider collaboration and increased citations

- maximum visibility for your research: over $100 \mathrm{M}$ website views per year

At BMC, research is always in progress.

Learn more biomedcentral.com/submissions 